\title{
Chapter 10 \\ Three Wax Images, Two Italian Gentlemen, and One English Queen
}

\author{
Brett D. Hirsch
}

In mid-August 1578, three wax images were discovered slowly melting under the gentle heat of a dunghill in London, one with the inscription 'Elizabeth' on its forehead and the others apparently dressed like privy councilors. When he reported this 'very curious thing' to his superiors, the Spanish ambassador Bernardino de Mendoza described how the effigies were 'covered over with a great variety of different signs', with 'the left side of the images being transfixed with a large quantity of pig's bristles as if it were some sort of witchcraft'. Queen Elizabeth, ill at the time, was understandably 'disturbed' by this augury, and 'great enquiries' were 'set on foot' by the privy council to uncover those responsible. ${ }^{1}$ In The Discovery of Witchcraft, Reginald Scot recalled 'the terror \& astonishment of manie thousands' occasioned by the event. ${ }^{2}$

Sometime between 1579 and 1584, a period in which witchcraft prosecutions and executions began to peak in England, and that witnessed intense government concern over the use of wax images as well as wider European publicity and comment on the situation, a play was performed at court before the queen. The play features an extended conjuration scene in which a wax image with a name inscribed on its forehead is covered over with marks and signs, anointed with oil, pricked with a needle through the heart, and melted by flame - all of the elements present in the 1578 case. The play is Fedele and Fortunio, printed in 1585 and advertised on its title page as 'a very pleasaunt and fine conceited Comoedie, of two Italian Gentlemen'. ${ }^{3}$ In the space of between one and five years, the use of such wax images - a practice of witchcraft so recently associated with treasonous attempts on the royal person and members of the privy council, and cause for national alarm - was an appropriate subject for comedy at court.

Fedele and Fortunio is a play much neglected by critics of early modern drama and witchcraft alike. Even Diane Purkiss's foundational study, The Witch in History, has little to say about the play. While recognising that the 1580 s and

1 Martin A.S. Hume, ed., Calendar of State Papers, Spanish (Simancas), 4 vols. (London: Public Records Office, 1892-1899), 2.611 (8 September 1578).

2 Reginald Scot, The Discovery of Witchcraft (Oxford, 1584), 2M5v. All subsequent citations are given as signature references in parentheses.

3 [A.M.], Fedele and Fortunio (London, 1585). All subsequent citations are given as signature references in parentheses. 
1590s were a period in which 'the nation, and especially the court, were working themselves up to fever pitch' over witchcraft, Purkiss mentions Fedele and Fortunio only in a footnote and erroneously credits Thomas Dekker's The Whore of Babylon (1604) with the first appearance of a witch using wax images on the English stage. ${ }^{4}$ There is no mention of the play in any of the scholarly monographs on witchcraft and magic in early modern English drama and culture produced in the last fifty years. ${ }^{5}$ Critical discussion of the play within the broader context of early modern drama and literature is similarly limited, in both quantity and scope. Editorial work on Fedele and Fortunio over the last century has produced only a single critical edition, ${ }^{6}$ while what little critical commentary has appeared in print - like the critical edition - has focused exclusively on issues of authorship, dating, and translation. ${ }^{7}$ The most recent monograph study of Anthony Munday,

4 Diane Purkiss, The Witch in History: Early Modern and Twentieth-Century Representations (New York: Routledge, 1996), 184-5, 194n13. Purkiss notes only that Fedele and Fortunio 'contains a classical witch in the person of Medusa' (196n29). Similarly, David Woodman mentions Fedele and Fortunio only in passing as a list of exemplars to be distinguished from what he calls 'white magicians' (White Magic and English Renaissance Drama [Rutherford: Fairleigh Dickinson University Press, 1973], 65).

5 This includes Genevieve Guenther, Magical Imaginations: Instrumental Aesthetics in the English Renaissance (Toronto: University of Toronto Press, 2012), Ryan Curtis Friesen, Supernatural Fiction in Early Modern Drama and Culture (Brighton: Sussex Academic Press, 2010), Heidi Breuer, Crafting the Witch: Gendering Magic in Medieval and Early Modern England (New York: Routledge, 2009), Ian McAdam, Magic and Masculinity in Early Modern English Drama (Pittsburgh: Duquesne University Press, 2009), Michael Mangan, Performing Dark Arts: A Cultural History of Conjuring (Bristol: Intellect, 2007), Dietmar Tatzl, 'Secret, black, and midnight hags': The Conception, Presentation, and Functions of Witches in English Renaissance Drama (Wien: Braumüller, 2005), Emma Wilby, Cunning Folk and Familiar Spirits: Shamanistic Visionary Traditions in Early Modern British Witchcraft and Magic (Brighton: Sussex Academic Press, 2005), James Sharpe, Witchcraft in Early Modern England (New York: Longman, 2001) and Instruments of Darkness: Witchcraft in England, 1550-1750 (London: Hamish Hamilton, 1996), Deborah Willis, Malevolent Nurture: Witch-Hunting and Maternal Power in Early Modern England (Ithaca: Cornell University Press, 1995), Elissa Hare, Enchanted Shows: Vision and Structure in Elizabethan and Shakespearean Comedy about Magic (New York: Garland, 1988), and K.M. Briggs, Pale Hecate's Team (London: Routledge \& Kegan Paul, 1962). Barbara Howard Traister's Heavenly Necromancers (Columbia: University of Missouri Press, 1984) admits that popular magic is beyond the purview of her study (20), and Anthony Harris's Night's Black Agents (Manchester: Manchester University Press, 1980 ) is limited to seventeenth-century drama.

6 Richard Hosley, ed., A Critical Edition of Anthony Munday's Fedele and Fortunio (New York: Garland, 1981). Percy Simpson prepared an earlier edition of the play for the Malone Society Reprints in 1909.

7 These include T.M. Parrott, 'The Authorship of Two Italian Gentlemen', Modern Philology 13.5 (1915): 241-51, Renata Oggero, “"Translated Out of Italian” From Pasqualigo to Munday: Rewriting Italian Comedy in Elizabethan England', Quaderni del Dipartimento di Linguistica 24 (2006): 127-64, Mariangela Tempera, 'Taming the Go-Betweens: Two Elizabethan Versions of Luigi Pasqualigo's Il Fedele', in Class, 
now generally accepted as the play's author, devotes only two pages to discussion of the play. ${ }^{8}$

The present collection offers a timely opportunity to shape critical discussion of the play. In order to so do, this chapter locates witchcraft as the central node of a network of disparate but linked cultural, historical, literary, and theatrical references illuminating (or illuminated by) Fedele and Fortunio.

\section{Knowns and Unknowns}

At a briefing to address mounting public concerns about the lack of evidence linking the Iraqi government to the supply of weapons of mass destruction in 2002, Donald Rumsfeld, then United States Secretary of Defense, offered the following statement to the press:

[T] here are known knowns; there are things we know we know. We also know there are known unknowns; that is to say we know there are some things we do not know. But there are also unknown unknowns - the ones we don't know we don't know. ${ }^{9}$

Uncertainties of the 'known unknown' type similarly dog early theatre history, and Fedele and Fortunio is a typical case. Anthony Munday's authorship of the play, though generally accepted and the most likely, is not a certainty: neither the quarto of 1585 - the single early edition of the play - nor its entry in the Stationers' Register on 12 November 1584 names its author, and press variants record the dedication as signed 'A.M.' or 'M.A.'. ${ }^{10}$ The relative paucity of surviving plays definitively attributed to Munday frustrates even the most robust computational methods of authorship attribution, since the available data from which to demarcate any authorial style in his drama is so limited. ${ }^{11}$ Until more powerful attribution

Boundary and Social Discourse in the Renaissance, ed. Alexander C.Y. Huang, I-Chun Wang, and Mary Theis (Kaohsiung: Center for Humanities and Social Sciences and the College of Liberal Arts, National Sun Yat-sen University, 2007), 87-106, and three articles by Richard Hosley: 'Anthony Munday, John Heardson, and the Authorship of Fedele and Fortunio', Modern Language Review 55 (1960): 564-5; 'The Authorship of Fedele and Fortunio', Huntington Library Quarterly 30 (1967): 315-30; and 'The Date of Fedele and Fortunio', Modern Language Review 57 (1962): 385-6.

8 Donna B. Hamilton, Anthony Munday and the Catholics, 1560-1633 (Farnham: Ashgate, 2005), 60-62.

9 US Department of Defense, 'Department of Defense News Briefing - Secretary Rumsfeld and Gen. Myers', News Transcript, February 12, 2002.

10 The play has also been attributed to George Chapman and Stephen Gosson. For a comprehensive survey and discussion of the authorship, see Hosley, A Critical Edition, $15-30$.

11 On the principles and practices of authorship attribution, see Harold Love, Attributing Authorship: An Introduction (Cambridge: Cambridge University Press, 2002). 
techniques become available or new evidence suggests otherwise, the authorship of Fedele and Fortunio remains a 'known unknown'.

The dates of the play's composition and first performances are also 'known unknowns'. The composition of Fedele and Fortunio must be some time between the publication of the second edition of Luigi Pasqualigo's Il Fedele (Venice, 1579), the version of the source freely adapted by the play's author, and its 1584 entry in the Stationers' Register. There is no internal evidence with which to further delineate these dates. Though the title page reports the play was 'presented before the Queenes moste excellent Maiestie' - a report reinforced by the inclusion of a 'Prologue before the Queene' (A2v) and an 'Epilogue at the Court' (H1v) there are no extant records with which to precisely date this court performance, to ascertain where it was presented or whether it was acted previously for public or private audiences, or to link the play with any repertory company. The play's most recent editor, Richard Hosley, argues persuasively that it was 'written for and originally performed by a children's company', given the many allusions 'to the customs, curricula, and pedagogical practices of grammar schools and petty schools' and stage directions 'calling for music at the end of each of the first four acts'. Convinced of Munday's authorship, Hosley conjectures that:

Fedele and Fortunio, having been performed at the Blackfriars during the early winter of 1583-84, was performed at Court on 6 January [Twelfth Night] or 2 February [Candlemas] of 1584 by Oxford's Boys under the name of one of their component companies, the Children of the Queen's Chapel. ${ }^{12}$

Hosley's conjecture has the benefit of linking the play with both the earl of Oxford, then Munday's patron, and a possible court performance some nine or ten months before its entry in the Stationers' Register. Though credible, it is still conjecture. Also assuming Munday's authorship, Donna B. Hamilton argues less convincingly for December 1584 as the date of performance by Oxford's company at Arundel House..$^{13}$ The problem, as Martin Wiggins notes, is that 'discontinuity, inconsistency, and incomplete evidence bedevil any attempt at a coherent account of the institutions of choirboy theatre' in the 1580s, with Revels accounts 'omit[ting] the usual details about what was performed at court and by whom' and Chamber accounts 'lump[ing] all the payments together' for seven plays 'in a single entry'. ${ }^{14}$ As with the play's authorship, the identity of its repertory company and precise dating of its early performances are likely to remain 'known unknowns'.

To conclude with Rumsfeld's inelegant (but nonetheless astute) taxonomy of certainties and uncertainties, the remainder of this chapter turns now to consider a number of well-documented historical, cultural, political events of the period 1578-1584 - 'known knowns' - as possible contexts for a deeper understanding

12 Hosley, A Critical Edition, 93-4.

13 Hamilton, Anthony Munday and the Catholics, 60.

14 Martin Wiggins, 'When did Marlowe Write Dido, Queen of Carthage?' Review of English Studies 59.241 (2008): 521-41 (531-2). 
and appreciation of Fedele and Fortunio. In so doing, I hope also to draw attention to the way such 'known knowns' and 'known unknowns' distort our sense of cultural, literary, and theatrical history. In the case of Fedele and Fortunio, the uncertainties of authorship, date, and occasion have permitted the play to drop out of critical view. As I argue in this chapter, the play's tantalisingly uncertain status reorients standing narratives about the relationship between witchcraft and drama. Rather than a mirror or parody of an antecedent reality, Fedele and Fortunio reverberates its own artificiality against that of its social, political, and religious circumstances.

\section{Wax Images}

magic, sympathetic. magic based on the belief that a magical practice performed on one object (or in one situation) can have an effect upon another object (or situation), either because the two objects were once associated with each other or because they are similar. ${ }^{15}$

The history of the use of human figurines or effigies (called 'poppets') ${ }^{16}$ for sympathetic magical practices in Europe dates back to antiquity. ${ }^{17}$ Poppets could be fashioned out of any material, organic or inorganic: in addition to figures made of wax or wood, 'numerous ancient poppets in lead and other metals' and 'in clay or mud, baked or unbaked, have survived'. ${ }^{18}$ These figures could range from realistic representations to crude abstractions, 'so long as they were ritually associated with particular people who were to be affected in some way'. ${ }^{19}$ Wax poppets were particularly popular in Christian Europe, given the mimetic capacity of the medium and the use of wax figures for orthodox purposes. 'Painted wax figures', Pamela Pilbeam observes, were 'an integral part of the ceremonies of the Roman Catholic Church' and were used 'in processions, religious and otherwise, since ancient times'. Moreover:

Wax was often used to make models of saints and of Jesus and Mary for use in churches. Although the Reformation eliminated them from churches in

15 G.A. Theodorson, ed., A Modern Dictionary of Sociology (London: Methuen, 1970), 239.

16 For a fascinating study of puppets - a cognate of the word 'poppets' - and their relationship to magic in early modern England, see Scott Cutler Shershow, Puppets and 'Popular' Culture (Ithaca: Cornell University Press, 1995), 13-42.

17 Plato, though he dismissed their magical efficacy, commented on the use of images of molded wax as portents (Laws 11.933b).

18 Marina Piranomonte, 'Religion and Magic at Rome: The Fountain of Anna Perenna', in Magical Practices in the Latin West, ed. Richard L. Gordon and Francisco Macro Simón (Leiden: Brill, 2010), 206.

19 Michael D. Bailey, Magic and Superstition in Europe: A Concise History from Antiquity to the Present (London: Rowman \& Littlefield, 2007), 87. 
Protestant states, voluptuous and colourful full-size wax models continued to adorn Roman Catholic churches, especially in Italy. ${ }^{20}$

Reformers also viciously attacked the practice of leaving ex votos - replicas fashioned out of wax or metal in the shape of whatever organ, limb, or figure (animal and human) required or had received miraculous intervention or cure - at the tombs and shrines of saints and their relics ${ }^{21}$ a medieval practice that rose in popularity in Catholic nations during the Counter-Reformation..$^{22}$

While the Reformation purged wax statuaries and votives from English churches and cathedrals, religious and secular practices incorporating wax figures that 'did not smack of Romish idolatry' survived. ${ }^{23}$ English royals adopted the ancient Roman custom of carrying realistic wax effigies as part of their funeral processions, a practice that originated with the life-size wax effigy of Henry III in 1272 and continued into the early eighteenth century. ${ }^{24}$ Wax seals used to secure letters in the medieval and early modern period, whether to evidence authority or ensure privacy, frequently depicted human figures. As James Daybell notes in his study of English letters, 'Royal seals depicted the monarch enthroned; bishop's seals usually presented a standing prelate; monastic seals depicted their buildings, figures of saints or biblical images', while 'personal seals varied greatly' ${ }^{25}$ Imbued with significant political power, royal seals, as with other images of the monarch, were sites of intense cultural anxiety whose uses (and abuses) the government monitored accordingly. ${ }^{26}$

In Elizabethan England, wax images depicting human figures therefore served a variety of functions: as instruments of power authorised and vigilantly policed by the state, as devotional objects alternatively condoned or condemned by the church,

20 Pamela Pilbeam, Madame Tussaud and the History of Waxworks (London: Continuum, 2003), 1.

21 On votive offerings in pre-Reformation England generally, see Ronald C. Finucane, Miracles and Pilgrims: Popular Beliefs in Medieval England (London: Dent, 1977).

22 Paolo Parigi, The Rationalization of Miracles (Cambridge: Cambridge University Press, 2012), 96.

23 Richard D. Altick, The Shows of London (New Haven: Harvard University Press, 1978), 50 .

24 See Sergio Bertelli, The King's Body: Sacred Rituals of Power in Medieval and Early Modern Europe, trans. R. Burr Litchfield (Philadelphia: University of Pennsylvania Press, 2001), 51, and Altick, The Shows of London, 50-63. On the broader history of wax figure sculpture, see Catherine Heard, 'Uneasy Associations: Wax Bodies Outside the Canon', in Leslie Boldt-Irons, Corrado Federici, and Ernesto Virgulti, eds, Disguise, Deception, Trompe-l'œil: Interdisciplinary Perspectives (New York: Peter Lang, 2009), 231-50.

25 James Daybell, The Material Letter in Early Modern England: Manuscript Letters and the Culture and Practices of Letter-Writing, 1512-1635 (New York: Palgrave, 2012), 105.

26 For an illuminating study of the anxieties surrounding representations of Elizabeth I, see Louis Montrose, The Subject of Elizabeth: Authority, Gender, and Representation (Chicago: University of Chicago Press, 2006). 
as commemorations of the dead, and as devices of witchcraft. Simultaneously occupying these political, cultural, religious, and emotional spaces, Elizabethan attitudes toward wax figures were complex, contradictory, and overlapping. ${ }^{27}$

Their ritual use in sympathetic magic could similarly serve a variety of functions, protective, amorous, or harmful. Plato, though he dismissed their supernatural power, noted the use of wax effigies as portents (Laws 11.933b). Reginald Scot, equally sceptical of their magical efficacy, recorded a number of contemporary Elizabethan uses, ranging from to 'hurt or kill' or 'to obteine a womans loue' (T1r). While the intentions and anticipated outcomes differed, the practices involved in (and the material products of) rituals of sympathetic magic using wax poppets appear indistinguishable: in all cases, an image is fashioned and associated with the victim in some way (symbolically, textually, materially), ritual words or actions of conjuration are performed, and the image is subjected to manipulation or torture. Scot's descriptions of Elizabethan practices follow this typical pattern. To 'hurt or kill', one must 'make an image in his name' in 'new virgine wax', 'hang about the necke thereof a new thred in a new needle pricked into the member which you would haue hurt', accompanied 'with the rehearsall of certeine words' (T1r). 'For a greater mischeefe', the same image made in the forme of a man or woman, vpon whose head is written the certeine name of the partie' to be affected, might instead have words of conjuration written 'on his or hir ribs' and then 'be buried' (T1r). Alternatively, 'to obteine a womans loue, an image must be made ... of virgine wax', again 'in the name of the beloued' (or victim, depending on one's perspective), 'whervpon a character is written' and the poppet is 'warmed at a fier, and in dooing thereof the name of some angell must be mentioned' (T1r).

The conjuration scene in Fedele and Fortunio dramatises the correspondence between practices of love magic and maleficium using wax poppets, distinguished only by intention. Hired by Victoria to obtain Fortunio's affections by magic, the witch Medusa presents 'the Image of a man, made out in Uirgin waxe' to be 'prickt' and 'toasted in the flame' (C2r). With Victoria's name inscribed on its 'brest' and Fortunio's on its 'forehead' (C4r), the poppet is then 'prickt' and 'set in greater heat' whilst Medusa conjures various spirits 'whose names are on this Image' $(\mathrm{C} 4 \mathrm{v})$. At the conclusion of the ritual, Medusa announces that she must 'stick a needle in his hart, / And prick him with the point', but 'If that I strike the needle through, the gentleman will dye' (D1r). Although resolved comically in Fedele and Fortunio, this similarity in process and product had potentially serious consequences. While physical resemblances or the names inscribed might identify their intended targets, wax poppets gave their discoverers no indication of their intended purpose. As a result, poppets used for love magic could be - and, as the 1578 case illustrates, were - mistaken as evidence of maleficium and vice versa.

Immediately after the wax images were discovered in 1578 , the privy council summoned the magus John Dee 'to prevent the mischief ... suspected to be

27 A more detailed examination of these attitudes is outside the purview of the present chapter. Interested readers are directed to the essays by Jessica Dell and Helen Ostovich in this collection. 
intended against her Majestie's person, by means of a certain image of wax, with a great pin stuck into it about the breast'. Dee performed charms against the suspected witchcraft and sought to identify those responsible 'in godly and artificial manner'. ${ }^{28}$ Fuelled by concomitant desires for further reformation of the English church and the derailment of the proposed marriage between Elizabeth and the Catholic François-Hercule, Duc d'Anjou, Protestant factions within the privy council led by the Earl of Leicester set out 'to find evidence of Catholic sorcery against Elizabeth, which he could use against his Catholic rivals at court'. ${ }^{29}$ Thus, the privy council instructed the bishop of London to investigate 'certeine personnes ... privie to the secrett keping of certeine images ... reserved to some ill purpose of sorcerie or idolatrie,' and ordered the bishop of Norwich to ensure that reports of images 'reserved to the privatt use of them that kepe them for idolitrie or for some other daungerous purpose of sorcerie or wichecraft' were likewise 'carefullie looked unto and mett withall by all meanes possible'. ${ }^{30}$

As the privy council 'used the wax images to justify punishing their hit list of Catholic recusant gentlemen', the investigations initially led to the arrest of a Catholic father and his son, the latter accusing Thomas Harding, the Protestant vicar of Islington himself previously investigated for conjuring, under severe torture. ${ }^{31}$ Although Leicester had both Harding (who failed to confess to his alleged secret Catholicism under torture) and John Prestall (a Catholic gentleman notorious for his attempted magical conspiracies against both Mary Tudor and Elizabeth I) condemned to death for high treason, lack of evidence ensured their release. ${ }^{32}$ More embarrassingly, Thomas Elkes, a Protestant conjuror, 'confessed that he had created the wax images to enable a wealthy young client to obtain a woman's love', ${ }^{33}$ and the queen's 'grievous pangs and pain' previously attributed to her bewitchment turned out to be 'toothake and the rheume'. ${ }^{34}$

As the unfolding events gained wider European publicity, ${ }^{35}$ Catholics seized the opportunity to comment on their unjustified persecution in this and other matters. One letter, purportedly written by a Spanish gentleman, refers to the case

28 John Dee, 'The Compendious Rehearsal of John Dee', in Johannis, confratris \& monachi Glastoniensis, chronica sive historia de rebus Glastoniensibus, 2 vols, ed. Thomas Hearne (Oxford, 1726), 2.521-2.

29 Glyn Parry, The Arch-Conjuror of England: John Dee (New Haven: Yale University Press, 2012), 132.

30 John Roche Dasent, ed., Acts of the Privy Council of England, new series, 46 vols. (London: Her Majesty's Stationery Office, 1890-1964), 11.36.

31 Parry, The Arch-Conjuror of England, 133.

32 On Prestall, see Michael J. Devine, 'John Prestall: A Complex Relationship with the Elizabethan Regime', MA thesis (Victoria University of Wellington, 2009).

33 Parry, The Arch-Conjuror of England, 136. As Parry notes, Elkes was subsequently condemned to death in November 1580 for conjuring, only to obtain his reprieve from the queen.

34 Dee, 'The Compendious Rehearsal', 522.

35 For example, the French jurist and demonologist Jean Bodin reports the incident in his influential De la Demonomanie des Sorciers (Paris, 1580), 2F4v-2G1r. 
in remarkable detail as part of an extended polemic about the 'deceatfull practises, false fictions, and slaunderous lies' of the English Crown towards Catholics at home and abroad:

You haue $\mathrm{h}[\mathrm{e}]$ ard of images of wax hidden in the earthe, whereof both bookes and ballettes were spred aboute the country, that this was don by Catholiques, to consume the Queene, and some other: for the which cause, one Hardinge a protestant minister of Islington was apprehended, charged that he was a Papist, moste cruelly racked, and vniustly condemned to death. And yo[u] haue vnderstood afterward, that one Elkes another protestant, confessed himself to haue been the doer there of: yet not to destroy the Queene, but to obtaine the loue of some Londoners wyf. ${ }^{36}$

This brings us back to the 'known unknown' of Fedele and Fortunio's authorship. The play's conjuration scene (2.2) takes place in a tomb, with Victoria, her maidservant Attilia, and the enchantress Medusa 'disguised like Nunnes' (C3v). These disguises, coupled with the play's Neapolitan setting, Italian title, and Medusa's use of Latin incantations - language usage that 'conflates Catholic practice with witchcraft' ${ }^{37}$ as in Doctor Faustus and elsewhere in the English drama - are frequently marshalled as evidence of anti-Catholicism in Fedele and Fortunio. Elizabeth Williamson, for example, considers the scene 'part of a series of humorous anti-Catholic tropes ... catering to members of the Protestant aristocracy ${ }^{38}$ Given what Donna B. Hamilton has described as the 'prevailing view' of Anthony Munday 'not only as a Protestant but as a "rabid" Protestant or as "rabidly" anti-Catholic or anti-papist', ${ }^{39}$ these alleged anti-Catholic tropes might support claims for Munday as the play's author. The text of the play certainly allows for such a reading: three Italian women disguised as nuns conjure spirits with Latin incantations and a wax image, only to flee when the devil appears after they complete the ritual by throwing their tapers into a tomb. The devil is in fact the clown figure Crackstone, who emerges from the tomb 'with one candel in his mouth, and in eche hand' (D1r). Critics have argued that this scene offers a 'send-up of the act of resurrection', with 'would-be witches, who impersonate nuns and commit sacrilege against the dead ... bested by a fake demon', encouraging its Protestant audience 'to witness and reaffirm the charlatanism of papists' ${ }^{40}$ Elizabethan Protestants, particularly those hard-line

36 Richard Verstegan, trans., The Copy of a Letter Lately Written by a Spanishe Gentleman (Antwerp, 1589), A3v-A4r.

37 Janette Dillon, Language and Stage in Medieval and Renaissance England (Cambridge: Cambridge University Press, 1998), 194. On Doctor Faustus, see Chapter 8, 'Rebels and Outcasts.'

38 Elizabeth Williamson, The Materiality of Religion in Early Modern English Drama (Farnham: Ashgate, 2009), 51.

39 Hamilton, Anthony Munday and the Catholics, xvi. Hamilton surveys these classifications at xvi, and in passim.

40 Williamson, The Materiality of Religion, 51-2. See also Richard Wilson, Secret Shakespeare: Studies in Theatre, Religion and Resistance (Manchester: Manchester University Press, 2004), 83-7. 
factions at court, would have approved of the scene's linking of Catholicism with idolatry, superstition, and ineffective sorcery.

Munday's authorship of the play, however, as outlined above, is far from conclusive, and, as Hamilton has persuasively shown, neither is his precise religious affiliation: he may well have been a Catholic, whether lapsed, loyal, or otherwise. The author certainly adapts Pasqualigo's Italian original, which calls for the three women to enter the tomb dressed as servants ('uestite da serue') ${ }^{41}$ but English anti-clericalism, though thematically intertwined, is not necessarily identical to anti-Catholicism. Catholic or not, the author of Fedele and Fortunio passes up the opportunity afforded by the nun's habits to facilitate the sort of 'rabid' antiCatholic tropes one often expects in English drama of the period, instead offering them only as a more believable disguise for three women wishing to enter a chapel without raising suspicion. Moreover, given the widespread publicity of the 1578 witchcraft scare and the later apprehension of the (embarrassingly Protestant) culprit, the target of the scene's mockery instead may be the English authorities and the court itself for mistaking wax images used in love magic for evidence of Catholic maleficium directed at the queen.

In the prologue before the queen, the author admits he 'shootes at mirth, yet if he misse that white, / Your Highnesse pardon he dooth humbly craue' (A2v), and in the epilogue at court is 'Desiring pardon if he did offend' (H1v). ${ }^{42}$ Though the author of Fedele and Fortunio dutifully (and perhaps conventionally) acknowledged the possibility that his comedy might offend the sovereign, accounts of the performance of Fedele and Fortunio at court do not survive. Like the identity of the play's author and his particular religious affiliation, how its courtly audience, Elizabeth in particular, reacted to the comedy and its dramatisation of sympathetic magic rituals with wax images - rituals and ritual objects so recently a cause for national alarm, and national embarrassment - remains a 'known unknown'.

\section{Monarchs, Medusas, and Marriage}

In both the Italian original and the English adaptation, the humour of the conjuration scene is perhaps more misogynistic than theological. Whether disguised as nuns or servants, the description of the three women by an unseen male onlooker is equally unflattering: in both versions, the women are devils and cattle. ${ }^{43}$ In Pasqualigo's original, Renata Oggero has shown, 'women are monotonously targeted with

41 Luigi Pasqualigo, Il Fedele (Venice, 1579), C2v. All subsequent citations are given as signature references in parentheses.

42 On the conventions of prologues and epilogues and various instances of departure from them in the early modern drama, see Brian W. Schneider, The Framing Text in Early Modern English Drama: 'Whining' Prologues and 'Armed' Epilogues (Farnham: Ashgate, 2011).

43 Il Fedele: 'Che Diauolo sono queste Femine ... ò che cricca di Vacche' (C2v); Fedele and Fortunio: 'O che cricca di vacche? what cattell haue we heare? / Be they women, or deuils in the likenes of women that appeare?' (C3v). 
accusations of cruelty, immorality, ingratitude, unfaithfulness, inconstancy, irrationality, lechery and deceitfulness' - at one point described by Fortunio 'as the basest animal on earth', whose only 'intellectual capacity consists in their ability to manipulate those men ... foolish enough to fall in love with them' ${ }^{44}$ Through the selective excising of scenes, dialogue, and as many as six of the original characters, 'the promiscuous society of the Italian play is considerably reformed' in the English adaptation, ${ }^{45}$ but an undercurrent of misogynistic humour remains.

Amidst these cuts, alterations, and modifications, the play's English adapter left the original name of the witch figure, Medusa, unchanged. While the trisyllable name may simply have proved conducive to the rendering of Pasqualigo's Italian prose into English poetry, the peculiar associations of the word for an English audience bear further consideration. Besides more negative associations, as Lowell Gallagher has shown, English authors deployed the image of Medusa to mythologise Elizabeth as an icon of inviolability and royal omnipotence, particularly in the face of conspiracies against her life: 'Even if conspirators managed to come within striking distance of the queen's body, they would find themselves, mysteriously, immobilized in her presence'. ${ }^{46}$ Gallagher offers Richard Crompton's A Short Declaration of the Ende of Traytors as an example, written in the wake of the Throckmorton and Babington plots, in which that author reminds Elizabeth:

Comfort your selfe also in this, that they ... which haue thus conspired to take your Maiesty from vs, when they haue come into your presence, meaning then to haue accomplished theyr most trayterous purpose, haue beene so diswayed vpon the sight of your princely person, and in beholding your most gracious countenaunce, that they hadde no power to performe the thing, which they had before determined vppon. ${ }^{47}$

The prologue to Fedele and Fortunio, spoken 'before the Queene', reflects this 'fiction of the petrifying gaze, the localized medusan power of the monarch' ${ }^{48}$ It begins:

On euery syde where I this instant gaze,

The glimse of honour dimmes my dazeled eye:

Which sight may set a stouter in a maze,

And cheefely him that pende this Comoedie. (A2v)

44 Oggero, “"Translated Out of Italian”, 136-7. The relevant passage from Pasqualigo is 'non ui è animale nel mondo piu uile della Donna, la quale conoscendosi tale, \& in cio solo mostra la femina d'hauer intelletto, tiene nel suo segreto per bestia ciascun buomo, che l'ama, che la desidera, \& che la segue' (D7r).

45 Ibid., 151. For a table of corresponding episodes in Il Fedele and Fedele and Fortunio, see the Appendix to Hosley's edition, 237-51.

46 Lowell Gallagher, Medusa's Gaze: Casuistry and Conscience in the Renaissance (Stanford: Stanford University Press, 1991), 24.

47 Richard Crompton, A Short Declaration of the Ende of Traytors (London, 1587), sig. B2r.

48 Gallagher, Medusa's Gaze, 24. 
References to the monarch's power to astonish visually and viscerally those in her presence - 'gaze', 'glimse', 'dimmes', 'dazeled', 'eye', 'sight', and 'maze' conclude with her association with classical divinity and the power of the sun to blind and burn: 'With Phoebus cast your fierie blaze asyde: / That meaner men your presence may abyde' (A2v). Edmund Spenser, whose Faerie Queene is 'arguably the most impressive ... and most influential' of the 'many poetic monuments ostentatiously erected' in praise of Elizabeth I, ${ }^{49}$ would later use the same image in his Epithalamion to liken his bride's ability to astonish the viewer with her 'inward beauty' to 'Medusaes mazeful hed', able to turn men to stone. ${ }^{50}$

Beyond its relationship to power and spectatorship, the image of Medusa was conducive to another powerful myth of Elizabeth - her virginity. Elizabethans were familiar enough with the story of Perseus beheading the Gorgon with the aid of Pallas Athena/Minerva's shield, on whose mirrored surface the image of Medusa is blazon. As the goddess of wisdom and chastity, Pallas Athena/ Minerva was a fitting association for the Virgin Queen, ${ }^{51}$ an image of Elizabeth cultivated in opposition to the proposed Anglo-French match and 'given pictorial representation for the first time during the debate on the Anjou marriage in the series of some seven "Sieve" portraits painted between 1579 and about 1583'. ${ }^{52}$ Of course, authors frequently inverted these positive associations: William Averell, for example, employs Medusa as an emblem of monstrous feminine sexuality in his polemic against the apparel, cosmetics, and 'finenes superficiall' that render women 'sluttish and bestiall' and cause those men who 'affectionatlie gaze on their painted pride' to 'lose the reason of men and become like stones'. ${ }^{53}$

While the prologue of Fedele and Fortunio, like Perseus, may have held up a mirror to Elizabeth as a Medusa figure, her Neapolitan namesake in the play reflected other aspects of the English monarch. Whereas Pasqualigo's original has her 'aiding and abetting rape and adultery', Medusa instead performs a 'timehonoured comic function' in the English adaptation, in which she 'schemes in order to guarantee that each Jack will have his Jill'. ${ }^{4}$ Far from the liminal and criminal character of the original, the Medusa of Fedele and Fortunio is 'a cunning

49 Dieter Mehl, 'Edmund Spenser's Gloriana: Elizabeth as "Faerie Queene"', in Queen Elizabeth I: Past and Present, ed. Christa Jansohn (Münster: Lit Verlag, 2004), 89-100 (89); and Robin H. Wells, Spenser's Faerie Queene and the Cult of Elizabeth (London: Croom Helm, 1983).

50 Edmund Spenser, Amoretti and Epithalamion (London, 1595), H1r.

51 On the Renaissance iconography of Pallas Athena/Minerva, see Rudolf Wittkower, 'Transformations of Minerva in Renaissance Imagery', Journal of the Warburg Institute 2.3 (1939): 194-205. See also Julia M. Walker, Medusa's Mirrors: Spenser, Shakespeare, Milton, and the Metamorphosis of the Female Self (Newark: University of Delaware Press, 1998).

52 Susan Doran, Monarchy and Matrimony: The Courtships of Elizabeth I (London: Routledge, 1996), 171.

53 William Averell, A Mervailous Combat of Contrarieties (London, 1588), B1v.

54 Tempera, 'Taming the Go-Betweens', 103. 
broker' (F1v), the consummate go-between, whose politic efforts behind-thescenes ensure a comic resolution to the play in which female honour and chastity are maintained. The composition and first performance of Fedele and Fortunio sometime between 1579 and 1584 coincides with Elizabeth's own politic behindthe-scenes efforts to secure a marriage to the Catholic Duc d'Anjou - a prospective match that divided her court, fractured her privy council, and occasioned much public comment and censure:

Controversy over Anjou intensified in this period .... [H]er obvious interest aroused xenophobic opposition well beyond the court, leading Elizabeth to attempt to prevent discussion from spilling into public forums by strictly forbidding sermons and printed tracts on the subject. She did not succeed. Anonymous lampoons and ballads attacking Anjou circulated in London. ${ }^{55}$

As both mirror and mirrored, Medusa's first speech in Fedele and Fortunio resonates with these pressing domestic concerns: 'O foolish looue, and loouers that look not to their state, / But swimme against the tide, and then repent when tis too late' (C1r). By pursuing a match with a Catholic and 'swimm[ing] against the tide' of popular opinion, Elizabeth threatened both the Protestant 'state' of England and her 'state' as Virgin Queen. The government, 'fearing that the popular hostility might cause insurrection or disturbance, ${ }^{56}$ took this threat seriously, and the 'Protestant public relations campaign' ultimately succeeded in breaking down the marriage negotiations by $1581 .^{57}$ The conclusion of Medusa's first speech may also allude to the queen's neglect of English suitors, like Leicester, closer to home and theological orientation: 'When wee be coy, and holde our freendes aloofe at cap and knee: / The Mart is marde, and euery eye our folly then dooth see' (C1r).

Anjou died of a fever on 10 June 1584 at Château-Thierry, France, and any hopes of an Anglo-French match died with him. When she heard of his death, 'Elizabeth was greatly grieved' and 'wept in public every day for three weeks', with the court 'put into mourning' and the queen 'wearing black for six months', ${ }^{5}$ Were Fedele and Fortunio performed in 1584, it was grim timing for a romantic comedy about courtship and marriage.

55 R. Malcolm Smuts, 'Occasional Events, Literary Texts and Historical Interpretations', in Neo-Historicism: Studies in Renaissance Literature, History, and Politics, ed. Robin Headlam Wells, Glenn Burgess, and Rowland Wymer (Cambridge: D.S. Brewer, 2000), 191. See also Doran 1996, Doris Adler, 'Imaginary Toads in Real Gardens', English Literary Renaissance 11 (1981): 235-60, and Natalie Mears, 'Love-Making and Diplomacy: Elizabeth I and the Anjou Marriage Negotiations, c.1578-1582', History 86.284 (2001): 442-66.

56 Blair Worden, The Sound of Virtue: Philip Sidney's Arcadia and Elizabethan Politics (New Haven: Yale University Press, 1996), 110.

57 Doran, Monarchy and Matrimony, 125.

58 Alison Weir, Elizabeth, the Queen (London: Jonathan Cape, 1998), 350. 


\section{Rumsfeld Redivivus}

The tantalisingly uncertain contexts of the play - its authorship, date, occasion, and politics - bear an uncanny resemblance to the tantalising uncertainty of the wax figures themselves. The play's ambivalent status seems to recapitulate the cultural act dramatized in the conjuration scene: art (a play) imitating art (a wax figure), both of which have material consequences - both produce 'known unknowns'. Many such 'known unknowns' uncovered by this chapter stem from the apparent comedic capital Fedele and Fortunio makes out of phenomena that, just a few years earlier, provoked a spike in witchcraft paranoia and prosecution. The evidence presented here and in other chapters in this collection suggests that witchcraft and its discourses are not stable, but rather pliable and multiform. Whether the play is making an overt political statement remains a 'known unknown' that we can only speculate upon; that it also represents, revives, and resonates with real events perhaps too soon after their occurrence - is now a 'known known'.

\section{Acknowledgements}

I am indebted to Jonathan P. Lamb for his encouraging and insightful comments on this essay, and to Jenna Mead for convincing me that uncovering 'unknowns' is as valuable and rewarding an act of scholarship as interpreting 'knowns'. 